\title{
Purinergic P1 Receptor
}

National Cancer Institute

\section{Source}

National Cancer Institute. Purinergic P1 Receptor. NCI Thesaurus. Code C16262.

One of the purinergic P1 receptors that prefers adenosine to other endogenous purines. 